\title{
Perbedaan Efektivitas Parasetamol Oral Dengan Tramadol Oral Sebagai Tatalaksana Nyeri Pasca Operasi Transurethral Resection of The Prostate
}

\author{
Ismail Muhammad, Alvarino, Nasman Puar, Hafni Bachtiar
}

\begin{abstract}
Abstrak
Pendahuluan. Transurethral Resection of The Prostate (TURP) merupakan tindakan operasi endoskopi yang sudah menjadi standar baku untuk penatalaksanaan pembesaran kelenjar prostat jinak yang memerlukan tindakan bedah. Nyeri pasca operasi TURP disebabkan karena trauma (reseksi jaringan prostat), iritasi foley kateter dan traksi kateter pasca TURP pada luka operasi.

Metode. Merupakan jenis penelitian eksperimental yang membandingkan efektivitas pemakaian parasetamol oral 500 $\mathrm{mg}$ dengan tramadol oral $50 \mathrm{mg}$ sebagai tatalaksana nyeri pasca TURP. Penelitian ini melibatkan 30 orang pasien yang dibagi 2 kelompok yaitu 15 orang kelompok parasetamol dan 15 orang kelompok tramadol. Intensitas nyeri dengan skala VAS dan efek samping obat dinilai pada 3jam, 5jam, 7jam pasca spinal anesthesia. Hasil penelitian kemudian diuji dengan independen T.test dan Chi-square.

Hasil. Rata-rata nilai VAS 3 jam pasca spinal anastesia kelompok parasetamol adalah 0,6267 $\mathrm{cm}$ dan tramadol $0,6400 \mathrm{~cm}$. Pada 5 jam pasca spinal anastesi rata-rata nilai VAS kelompok parasetamol 1,5800 cm, kelompok tramadol $1,4933 \mathrm{~cm}$. Pada 7 jam pasca spinal anesthesia rata-rata nilai VAS kelompok parasetamol $3,5800 \mathrm{~cm}$ dan kelompok tramadol $3,1667 \mathrm{~cm}$. Setelah uji statistik baik pada 3jam, 5jam, 7jam pasca spinal anesthesia tidak terdapat perbedaan yang bermakna intensitas nyeri pada ke 2 kelompok dengan $p>0,05$. Sedangkan kejadian mual dan alergi juga tidak ada perbedaan yang bermakna pada kedua kelompok. $p>0,05$.

Kesimpulan. Parasetamol $500 \mathrm{mg}$ oral versus tramadol $50 \mathrm{mg}$ oral memiliki efektifitas yang sama dalam mengatasi nyeri pasca operasi TURP. Sedangkan kejadian mual dan alergi tidak ada perbedaan yang bermakna pada ke 2 kelompok.Kata kunci: TURP, parasetamol, tramadol, VAS
\end{abstract}

\begin{abstract}
Arial 9 italic Introduction. Transurethral Resection of the Prostate (TURP) is an endoscopic surgery that become the gold standard for the treatment of benign enlargement of the prostate gland that requires surgery. Postoperative pain due to trauma TURP (resection of prostate tissue), irritation foley catheters and catheter traction after TURP surgery on the wound. Methods. This study was an experimental research that compares the effectiveness of the use of oral paracetamol $500 \mathrm{mg}$ with $50 \mathrm{mg}$ oral tramadol as a pain management of post-TURP. This study involved 30 patients divided into 2 groups: 15 people group of paracetamol and 15 people group of tramadol. Pain intensity with the VAS scale and drug side effects rated at 3 hours, 5 hours, 7 hours after spinal anesthesia. Results were then tested with independent T.test and Chi-square Results were then tested with independent T.test and Chisquare. Results. Mean VAS values after 3 hours spinal anesthesia group of paracetamol and tramadol were 0.6267 $\mathrm{cm} 0.6400 \mathrm{~cm}$. At 5 hours after spinal anesthesia the mean VAS value of paracetamol group was $1.5800 \mathrm{~cm}$, group of tramadol was $1.4933 \mathrm{~cm}$. At 7 hours after spinal anesthesia mean VAS value group of paracetamol was $3.5800 \mathrm{~cm}$ and group of tramadol was $3.1667 \mathrm{~cm}$. After a statistical test at 3 hours, 5 hours, 7 hours after spinal anesthesia, we conclude that there was no significant difference in pain intensity on the 2 groups with $P>0.05$. While the incidence of nausea and allergies also had no significant difference in both groups. $P>0.05$. Conclusion. Paracetamol $500 \mathrm{mg}$ orally versus tramadol $50 \mathrm{mg}$ orally had the same effectiveness in addressing postoperative pain TURP. While there was no significant difference in the 2 groups in the incidence of nausea and allergies
\end{abstract}

Keywords:TURP, paracetamol, tramadol, VAS

Affiliasi penulis Fakultas Kedokteran Universitas Andalas Korespondensi Ismail Muhammad. Fakultas Kedokteran Universitas Andalas

\section{Pendahuluan}

Transurethral Resection of The Prostate (TURP) merupakan tindakan operasi endoskopi yang pertama dikembangkan di Amerika Serikat pada tahun 1920-an dan 1930-an dan sudah menjadi standar baku sampai saat ini untuk penatalaksanaan pembesaran kelenjar prostat jinak yang memerlukan tindakan bedah. ${ }^{(1,2)}$ Nyeri merupakan salah satu gejala yang sering timbul pasca bedah dimana melibatkan empat proses fisiologis: transduction, transmission, modulation dan perception. $^{(3)}$ Nyeri pasca operasi TURP disebabkan karena trauma (reseksi jaringan prostat), iritasi foley kateter dan traksi kateter pasca TURP pada luka operasi. $^{(4,5,6)}$

Kara $C$ et al Februari 2010 membandingkan efektifitas pemakaian Non Steroid Anti Inflamasi Drugs (NSAID) injeksi diklofenak dengan parasetamol drip. Kara $\mathrm{C}$ et all mendapatkan rata-rata nilai VAS pada kedua kelompok adalah $>3 \mathrm{~cm}$ pada 30 menit sampai 4 jam pertama pasca TURP Tetapi 6 jam berikutnya 
terjadi peningkatan yang signifikan pada parasetamol dibandingkan dengan diklofenak.. ${ }^{(6)}$

Pemakaian parasetamol oral dan tramadol ora sebagai analgetik pasca operasi sangat banyak bahkan termasuk salah satu analgetik yang direkomendasikan dalam guidelines manajemen nyeri pasca TURP oleh European Association of Urology. Untuk tramadol diberikan secara oral, im, sc atau iv dengan dosis 50 - $100 \mathrm{mg}$ tiap 6 jam. Sedangkan parasetamol diberikan secara oral atau iv dengan dosis $500-1000 \mathrm{mg}$ diberikan tiap 6 jam. ${ }^{7,8,9}$

Mekanisme kerja parasetamol yang diduga sebagai efek sentral seperti salisilat walaupun bersifat lemah parasetamol merupakan penghambat biosintesis prostaglandin dengan menghambat pelepasan enzim siklooksigenase (COX: cyclooxigenase) yang merubah asam arakidonat menjadi prostaglandin. Khusus parasetamol adalah penghambat $C O X-3$ yang hanya ada diotak yaitu dihipotalamus yang rendah kadar peroksida. (Efek analgetik tramadol dihasilkan oleh penghambatan reuptake norepinefrin dan pelepasan serotonin. Sedangkan tramadol sama efektifnya dengan morfin atau meperidin untuk nyeri ringan sampai sedang, tetapi lebih lemah untuk nyeri berat atau kronik. ${ }^{(9,10)}$

\section{Metode Penelitian}

Merupakan penelitian eksperimental yang dilakukan dalam waktu 3 bulan di RSUP Dr. M. Djamil dengan melibatkan 30 orang pasien yang didiagnosa $\mathrm{BPH}$ dan memenuhi kriteria inklusi. Penelitian ini dibagi dua kelompok yaitu kelompok I diberikan parasetamol oral $500 \mathrm{mg}$ dan kelompok II diberikan tramadol oral $50 \mathrm{mg}$ sebagai tatalaksana nyeri pasca TURP. ${ }^{(11,12,13)}$

Pembiusan dilakukan dengan teknik regional/spinal anastesia dengan obat bupivacain/ levobupivacain $20 \mathrm{mg} / 4 \mathrm{cc}{ }^{(14,15)}$ tanpa penambahan morfin intratekal maupun analgetik lainnya selama masa perioperatif. Lama operasi dibatasi maksimal 90 menit, untuk mengontrol perdarahan paska operasi pasien dipasang kateter urine no 24 dan ditraksi dengan berat beban traksi homogen ditetapkan 1000cc aquadest yang difiksasi pada paha kanan pasien dan traksi kateter dilepas bila dalam beberapa jam drainase bulibuli sudah jernih. ${ }^{(4)}$

Pemberian obat oral analgetik parasetamol 500 $\mathrm{mg}$ atau Tramadol $50 \mathrm{mg}$ pada masing-masing kelompok perlakuan langsung diberikan pasca operasi tepatnya 2 jam pasca spinal anesthesia secara double-blind. Kemudian peneliti melakukan pengamatan dan menilai derajat intensitas nyeri dengan memakai kuesioner VAS yaitu dengan cara meminta kepada pasien yang telah diberi penjelasan sebelumnya untuk menilai sendiri tingkat nyeri yang dirasakannya dan memberikan tanda pada skala VAS yang berupa garis lurus $0-10 \mathrm{~cm}$. Pengamatan nyeri pada skala VAS dan efek samping obat dilakukan sebanyak 3 kali yaitu 3 jam, 5 jam, 7 jam pasca spinal anesthesia.

Setelah data diperoleh kemudian diolah dan disajikan dalam bentuk tabel dan untuk mengetahui perbedaan intensitas nyeri maupun efek samping obat pada kedua kelompok dilakukan uji t dan chi-square dengan nilai $\alpha=0,05$ diambil sebagai batas kemaknaan. ${ }^{(11,13,16)}$

Hasil Penelitian

Tabel 1. Nilai VAS pada 3 jam pasca spinal anastesi.

\begin{tabular}{lllll}
\hline Nama Obat & Mean & SD & $\mathbf{p}$ & $\mathbf{n}$ \\
\hline $\begin{array}{l}\text { Parasetamol } \\
\text { 500mg }\end{array}$ & 0,6267 & 0,50493 & & 15 \\
$\begin{array}{l}\text { Tramadol } \\
\mathbf{5 0} \mathbf{~ m g}\end{array}$ & 0,6400 & 0,59618 & 0,948 & \\
& & & & 15 \\
\end{tabular}

Dari tabel diatas terlihat dengan pemakaian parasetamol oral $500 \mathrm{mg}$ rata-rata nilai VAS 3 jam pasca spinal anastesia adalah 0,6267 $\mathrm{cm}$ dan standar deviasi $0,50493 \mathrm{~cm}$, sedangkan dengan pemakaian tramadol oral $50 \mathrm{mg}$ rata-rata nilai VAS 3 jam pasca spinal anastesia adalah $0,6400 \mathrm{~cm}$ dan standar deviasi $0,59618 \mathrm{~cm}$. Dari hasil uji statistik didapatkan nilai $p=0,948$. Hal ini menunjukkan tidak ada perbedaan intensitas nyeri yang signifikan pada kedua kelompok.

Tabel 2. Niilai VAS pada 5 jam pasca spinal anastesi.

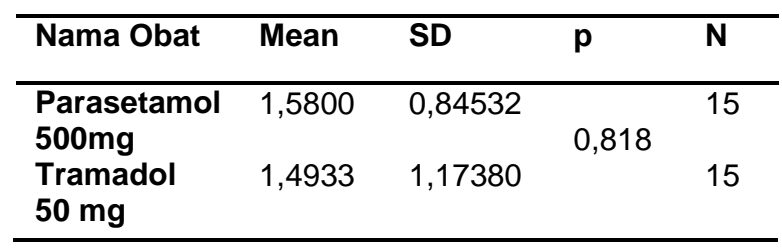

Dari tabel diatas, terlihat dengan pemakaian parasetamol oral $500 \mathrm{mg}$ rata-rata nilai VAS 5 jam pasca spinal anastesi adalah $1,5800 \mathrm{~cm}$ dan standar deviasi 0,84532 $\mathrm{cm}$, sedangkan dengan pemakaian tramadol oral $50 \mathrm{mg}$ rata-rata nilai VAS 5 jam setelah spinal anastesi adalah $1,4933 \mathrm{~cm}$ dan standar deviasi $1,17380 \mathrm{~cm}$. Dari hasil uji statistik didapatkan nilai $\mathrm{p}=0,818$, hal ini menunjukkan tidak terdapat perbedaan intensitas nyeri yang signifikan pada kedua kelompok.

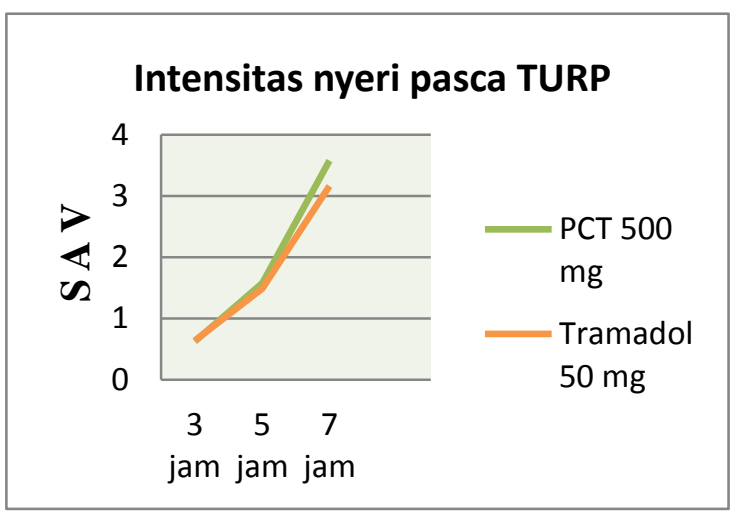

Tabel 3. Nilai VAS pada 7 jam pasca spinal anastesi.

\begin{tabular}{|c|c|c|c|c|}
\hline Obat & Mean & SD & $p$ & $\mathbf{N}$ \\
\hline $\begin{array}{l}\text { Parasetamol } \\
500 \mathrm{mg}\end{array}$ & 3,5800 & 2,07647 & 0,580 & 15 \\
\hline $\begin{array}{l}\text { Tramadol } \\
50 \mathrm{mg}\end{array}$ & 3,1667 & 1,96420 & & 15 \\
\hline
\end{tabular}


VAS 7 jam pasca spinal anastesi adalah $3,5800 \mathrm{~cm}$ dan standar deviasi $2,07647 \mathrm{~cm}$, sedangkan dengan pemakaian tramadol oral $50 \mathrm{mg}$ rata-rata nilai VAS 7 jam pasca spinal anastesi adalah $3,1667 \mathrm{~cm}$ dan standar deviasi $1,96420 \mathrm{~cm}$. Dari hasil uji statistk didapatkan nilai $p=0,580$. Hal ini menunjukkan tidak ada perbedaan intensitas nyeri yang signifikan pada kedua kelompok.

Grafik perbedaan intensitas nyeri antara parasetamol dan tramadol.

Tabel 4. Hubungan pemakaian obat dengan mual.

\begin{tabular}{llllllll}
\hline \multirow{2}{*}{ Kelompok } & \multicolumn{3}{l}{ Mual } & \multicolumn{4}{l}{ Ada } \\
\cline { 2 - 6 } & F & $\%$ & $\mathbf{f}$ & $\%$ & $\mathbf{f}$ & $\%$ \\
Parasetamol & 13 & 86,7 & 2 & 13,3 & 15 & 100 \\
Tramadol & 10 & 66,7 & 5 & 33,3 & 15 & 100 \\
Jumlah & 23 & 76,7 & 7 & 23,3 & 30 & 100 \\
\hline & & & & \multicolumn{5}{c}{$\mathrm{p}=0,390$}
\end{tabular}

Pada tabel diatas terlihat bahwa dari 15 pasien yang menggunakan paresetamol oral $500 \mathrm{mg}$ dan 15 pasien yang menggunakan tramadol oral $50 \mathrm{mg}$ sebagai analgetik pasca TURP menunjukkan angka kejadian mual lebih tinggi pada tramadol sebanyak 5 pasien $(33,3 \%)$ dari pada parasetamol sebanyak 2 pasien (13,3\%). Tetapi dari hasil uji statistik diperoleh nilai $p=0,390$ hal ini menunjukkan bahwa angka kejadian mual tidak menunjukkan perbedaan yang bermakna pada kedua kelompok.

Tabel 5. Hubungan Pemakaian Obat Dengan Alergi.

\begin{tabular}{|c|c|c|c|c|c|c|}
\hline \multirow{3}{*}{ Jenis Obat } & \multicolumn{4}{|c|}{ Alergi } & \multirow{2}{*}{\multicolumn{2}{|c|}{ Total }} \\
\hline & \multicolumn{2}{|c|}{ Tidak } & \multicolumn{2}{|c|}{ Ada } & & \\
\hline & $\mathbf{F}$ & $\%$ & $\mathbf{F}$ & $\%$ & f & $\%$ \\
\hline Parasetamol & 14 & 93,3 & 1 & 6,7 & 15 & 100 \\
\hline Tramadol & 1 & 100 & 0 & 0 & 15 & 100 \\
\hline Jumlah & 29 & 96,7 & 1 & 3,3 & 30 & 100 \\
\hline
\end{tabular}

Dari tabel diatas terlihat bahwa dari 15 pasien yang menggunakan parasetamol oral $500 \mathrm{mg}$ dan 15 pasien yang menggunakan tramadol oral $50 \mathrm{mg}$ sebagai analgetik pasca TURP, menunjukkan bahwa angka kejadian alergi hanya terjadi pada parasetamol sebanyak 1 pasien $(6,7 \%)$ dan tidak ada yang alergi pada kelompok tramadol (0\%). Dari hasil uji statistik diperoleh nilai $p=1,000$, hal ini menunjukkan bahwa angka kejadian alergi tidak menunjukkan perbedaan yang bermakna diantara kedua kelompok.

\section{Pembahasan}

Nyeri merupakan salah satu gejala yang sering timbul pasca bedah termasuk pasca TURP. Nyeri pasca TURP diakibatkan karena reseksi jaringan prostat, iritasi foley kateter dan traksi kateter pada luka operasi TURP..$^{(4,5,6)}$ Laporan tentang nyeri pasca TURP dan tatalaksananya masih sangat sedikit diperoleh dari publikasi. Dalam penelitian in membandingkan efektifitas parasetamol oral dan tramadol oral sebagai antinyeri pasca TURP pada 3, 5 dan 7 jam pasca spinal anestesia.

Pada 5 jam pertama pasca spinal sebagian besar pasien pada kedua kelompok merasa sangat nyaman dan sangat sedikit merasakan nyeri dengan nilai VAS rata-rata $<1,5 \mathrm{~cm}$. Akan tetapi peningkatan intensitas nyeri dengan nilai VAS rata-rata $3,37 \mathrm{~cm}$ terjadi pada 7 jam pasca spinal anesthesia pada kedua kelompok perlakuan, tetapi nilai ini masih termasuk katagori nyeri ringan yang masih bisa ditoleransi oleh pasien tanpa penambahan analgetik injeksi.

Pada 3 jam pasca spinal didapatkan rata-rata nilai VAS pada kelompok parasetamol adalah $0,63 \mathrm{~cm}$ dan kelompok tramadol adalah $0,64 \mathrm{~cm}$, dari hasil uji statistic perbedaan nilai VAS ini tidak bermakna secara signifikan pada kedua kelompok. Demikian juga rata-rata nilai VAS pada jam ke 5 dan 7 pasca spinal anestesia dari hasil uji statistic perbedaan nilai VAS ini tidak bermakna secara signifikan pada kedua kelompok.

Hasil penelitian ini berbeda dengan yang dilaporkan Kara C et al, Februari 2010, membandingkan efektifitas pemakaian Non Steroid Anti Inflamation Drugs (NSAID) injeksi diklofenak dengan parasetamol drip. Kara $\mathrm{C}$ et al mendapatkan rata-rata nilai VAS pada kedua kelompok adalah $>3$ $\mathrm{cm}$ pada 30 menit sampai 4 jam pertama pasca TURP. Tetapi 6 jam berikutnya terjadi peningkatan yang signifikan pada parasetamol dibandingkan dengan diklofenak. ${ }^{(6)}$ Perbedaan ini mungkin disebabkan karena adanya perbedaan teknik pembiusan, jumlah dosis dan cara pemberian obat analgetik selama perioperatif.

Sun Yeul Lee, MD, et al 2010 juga melaporkan pemberian parasetamol $1 \mathrm{~g}$ IV memiliki khasiat analgesik serupa dengan ketorolak $30 \mathrm{mg}$ IV pada pasien setelah menjalani operasi tiroidektomi sehingga parasetamol dijadikan alternative menggantikan ketorolak untuk nyeri ringan sampai sedang pada kondisi dimana NSAID tidak bisa digunakan. ${ }^{(17)}$

Melisa et al, 2005. juga Melaporkan pada 80 pasien pasca tiroidektomi dimana 40 pasien diintervensi dengan tramadol $1,5 \mathrm{mg}$ per $\mathrm{kg}$ BB IV dan 40 pasien kelompok kontrol diintervensi dengan proparasetamol 2gr. Pasca operasi diperoleh intensitas nyeri pada skala VAS menurun secara signifikan pada kedua kelompok perlakuan. ${ }^{(8)}$

Pada penelitian ini anesthesia spinal yang dilakukan tanpa penambahan morfin intratekal, sedangkan pengalaman selama ini biasanya dibagian anesthesia RSUP Dr.M.Djamil Padang setiap pasien operasi TURP dilakukan anesthesia dengan penambahan morfin intratekal sebagai adjuvan dan pemberian analgetik injeksi pasca operasi sehingga rata-rata nyeri hampir tidak dirasakan sama sekali oleh pasien selama 24 jam pertama pasca operasi kecuali kalau pasien mengalami retensi urine akibat bekuan darah dalam buli-buli. Kita ketahui bahwa efek samping pemberian morfin cukup banyak baik efek pada susunan saraf pusat maupun efek morfin didaerah perifer. Untuk itu sesuai dengan hasil penelitian ini dengan rata-rata nilai VAS tertinggi adalah $3,37 \mathrm{~cm}$ pada 7 jam pasca spinal anesthesia termasuk nyeri ringan sehingga perlu untuk dipikirkan kembali pemberian morfin intratekal dan analgetik injeksi pasca operasi apakah tetap diberikan atau cukup dengan pemberian parasetamol oral $500 \mathrm{mg}$ 
atau tramadol oral $50 \mathrm{mg}$ saja sebagai analgetik pasca operasi.

Dalam penelitian ini juga diperoleh angka kejadian mual lebih banyak dialami pada kelompok tramadol 5 orang $(33,3 \%)$ daripada kelompok parasetamol 2 orang $(13,3 \%)$, namun kejadian mual pada kedua kelompok tersebut setelah diuji statistik juga tidak menunjukkan perbedaan yang signifikan. Sesuai dengan literatur efek samping tramadol umumnya mual, muntah, mulut kering, lebih banyak dibanding dengan parasetamol. Hal ini sesuai dengan penelitian Pluim M. et. Al. 1999 yang melaporkan pada 38 pasien operasi elektif timbul mual lebih tinggi secara signifikan pada kelompok tramadol (84\%) dibandingkan parasetamol sebagai kelompok kontrol $(31 \%){ }^{(8)}$

Kejadian alergi dalam penelitian ini hanya terjad pada satu pasien $(6,7 \%)$ yang menggunakan parasetamol, sedangkan pada pasien yang menggunaka tramadol tidak ada yang terjadi alergi. Namun dalam uji statistik kejadian alergi tersebut juga tidak berbeda secara signifikan antara parasetamol dengan tramadol. Menurut literatur alergi bisa terjadi pada parasetamol namun biasanya sangat jarang terjadi. Namun kejadian alergi pada pasien kelompok parasetamol dalam penelitian ini belum tentu juga disebabkan oleh obat parasetamol, tapi bisa juga ksemungkinan disebabkan oleh obat-obat premedikasi seperti ranitidine, ondansetron. Sedangkan obat antibiotik yang diberikan adalah ceftriaxon. Efek samping ranitidine umumnya rendah, namun ruam pada kulit dan pruritus bisa terjadi sebagai efek samping yang tidak berhubungan dengan penghambatan reseptor $\mathrm{H}_{2}$. Ondansetron biasanya ditoleransi secara baik, gejala yang umum ditemukan adalah konstipasi ,sakit kepala, mengantuk dsb, tapi tidak dijelaskan mengenai efek gatal-gatal dan alergi pada kulit. Sedangkan reaksi alergi merupakan efek samping yang paling sering terjadi pada pemberian ceftriaxon, reaksi mendadak yaitu anafilaksis dengan spasme bronkus dan urtikaria dapat terjadi. ${ }^{(9,10)}$ Oleh karena itu kejadian alergi pada penelitian ini belum dapat dipastikan penyebabnya.

\section{Kesimpulan.}

Parasetamol $500 \mathrm{mg}$ oral versus tramadol $50 \mathrm{mg}$ oral memiliki efektifitas yang sama dalam mengatasi nyeri pasca operasi TURP dengan intensitas nyeri ringan yang dilakukan dalam teknik spinal anesthesia. Tidak ada perbedaan bermakna kejadian mual dan alergi pada pemberian paracetamol oral $500 \mathrm{mg}$ atau tramadol oral $50 \mathrm{mg}$ pasca TURP.

\section{Daftar Pustaka}

1. Wein. A J. Kavoussi,L R. et al. CampbellWalsh urology.-10th ed. International edition Philadelphia, Pennsylvania. Tahun 2012. Hal: 56-60

2. Kevin T. McVary. Management of benign prostatic hypertrophy. Northwestern University Feinberg School of Medicine, Chicago.Tahun 2004

3. Kirk R. M. MSFCS, Ribbans W. J, FRCS FRCS Ed orth "Clinical Surgery in General, RCS Course Manual' The Royal Free Hospital, London / UK, Northampton General Hospital, Northampton, UK. Fourth Edition Tahun 2004, Hal: 357-369.
4. Martin I. Resnick, lan M. Thompson Advanced Therapy of Prostate Disease Department of Urology Case Western Reserve University University Hospitals of Cleveland Cleveland, Ohio Tahun 2000, 584-590

5. Ariani D T, Umbas R, Rasyid N, Suprawati T E. Pengaruh Arah Traksi Kateter Terhadap Hemostasis dan derajat nyeri Pasca Reseksi Prostat Transuretra. Universitas Indonesia/ RSCM Jakarta 2010.

6. Kara. C, Resorlu B, et al. Analgesic Efficacy and safety of Nonsteroid Anti Inflammatory Drugs after Transurethral Resection of Prostate. Department of Urology, kecioren Training and Research Hospital, Ankara,Turkey. International Braz J Urol, vol. 36(1):49-54, January-February 2010.

7. Guidelines on Pain Management. P. Bader (chair), et al. European Association of Urology 2009. Hal 71-72

8. Mellisa $\mathrm{F}$ et al The effectiveness of tramadol in acute pain management Reviewers Research information specialist 2005

9. Katzung, Bertram G. Farmakology dasar dan klinik. Alih bahasa, staf dosen farmakologi fakultas kedokteran UNSRI. Editor, H. Azwar Agoes Ed. 6. Jakarta EGC, Tahun 1997. Hal: 479-495, 559-577

10. Farmakologi Dan Terapi / Departemen Farmakologi dan terapeutik Fakultas Kedokteran Universitas Indonesia Jakarta, edisi 5 2007. Hal: $210-246$

11. Natoatmojo $\mathrm{S}$ : Metodologi penelitian kesehatan- Ed. Rev - Jakarta Rineka Cipta Tahun 2010. Hal: $50-253$

12. Pratiknya, Ahmad Watik: Dasar - dasar Metodologi Penelitian Kedokteran Dan Kesehatan, -Ed 1, Cet 5-Jakarta: PT Raja Grafindo Persada, 2003, Hal: 68

13. Ariawan, Iwan: Besar dan Metode Sampel Pada Penelitian Kesehatan Jurusan Biostatistik dan Kependudukan Fakultass Kesehatan Msyarakat, Universitas Indonesia, Jakarta Tahun 1998. Hal: 51-57

14. Donald D.Miller. Miller's Anesthesia, seventh edition volume 2, tahun $2010 \quad$ hal: 1611-1619.

15. G. Edward Morgan, Jr. Clinical Anesthesiology, fourth edition hal: 309

16. Sutanto Priyo Hastono ,Drs, M.Kes : Basic Data Analysis for health research training. Fakultas Kesehatan Masyarakat Universitas Indonesia, Jakarta Tahun 2006

17. Sun Yeul Lee MD, et al : The Effects of Paracetamol, Ketorolac, and Paracetamol Plus Morphine on Pain Control after Thyroidectomy. Department of Anesthesiology and Pain Medicine, Chungnam National University School of Medicine, Daejeon, Korea. Juni 2010 